\title{
Reorganizing a South American University Library
}

Mr. McAnally is associate librarian in charge of public services, University of Illinois.

$\mathrm{T}$

HIS REPORT describes seven months' work as supervisor of libraries of the oldest university in the Americas, the Universidad Nacional Mayor de San Marcos, in Lima, Peru. The University of San Marcos was founded in $155 \mathrm{I}$ by royal order of the King of Spain and is now the chief national university of Peru. It is a typical South American university, better than many and perhaps not so good as others. It differs in many ways from U.S. institutions, and so do its libraries; these differences and the special problems that arise from them are described at length. The work performed was a reorganization of the library system, undertaken at the request of the university and with the cooperation of university authorities, the Library of Congress, and the Department of State. ${ }^{1}$ The viewpoint is that of an average university librarian from a small state university in the U.S.

Preliminary reading had shown the university to be different in several respects from those of the U.S., and it was obvious that no action should be taken on general library matters until the real nature of the institution was understood. Consequently the first steps after arrival and formal introduction were to read additional publications

1 A more detailed account of the work is given in the author's "La Reorganizacion de la Biblioteca Central de la Universidad Nacional Mayor de San Marcos." Boletin Bibliografico of the University, 18:1-12, June 1948 . about the university, including its reports and laws, ${ }^{2}$ to talk with deans, professors and students, and to visit the various libraries. Later a survey questionnaire was prepared and circulated to all faculty members and administrative officers. Although there was considerable formal protocol that could not be slighted, everyone was quite courteous and helpful, particularly the permanent director of the central library. After this brief period of orientation, the director of the central library was sent to the U.S. to study, and the writer was made supervisor of libraries, with his actions subject to the approval of the faculty library inspector and the rector or president. The position included complete authority over the main library and advisory responsibility for the others.

\section{The University}

The university is relatively independent of the national government, for although state supported, it does not need to seek annual appropriations and has no stateappointed board of regents. Income is derived from certain earmarked taxes and from land grants. This independence, incidentally, is one result of the famous university reform movement that swept all South America after 1919. One result of this freedom is that the university is usually a stronghold of liberalism and is sometimes rather critical of the national government.

\footnotetext{
2 The University publishes the annual reports of the rector, as Memorias. Laws are in the University's Boletin Universitario, vol. I, no. 1, June 1946 .
} 
The university is governed by a rector, elected for a five year term by certain full professors, and the University Council. This council is composed of the rector and vice rector, the Io academic deans, Io professors elected by the io faculties or colleges, and II students, io elected by the students of the respective colleges and one elected at large. This council approves all policies and budgets and is the final authority in all university matters. Such a system of government, so strange to North American universities, has both advantages and disadvantages, but they cannot be elaborated upon here.

Instruction is offered in to faculties or colleges plus a new university college which every student has to attend for two years of general education before entering the various professional schools. Each is governed by a dean and a council similar to the university administration and all are, relatively independent in internal matters. Some colleges have affiliated institutes and museums, such as of history, which were developed for research, public lectures and similar functions that are not a part of the general instructional program. Each college maintains some form of library.

Faculty members are elected and are almost all part-time professors; the institution suffers for this last. Salaries are quite low and apparently based upon the theory of independent income being available or upon other employment. Also, by going on a strike students can compel the resignation of an unsatisfactory faculty member or even a dean, but this is not common. These conditions are obvious handicaps, but nevertheless the university does secure a surprisingly good faculty, for it is an honor to be a professor in the university and the honor is taken seriously. Instruction used to be preponderantly by lectures, but many newer methods of teaching have been introduced from
French and more recently from North American universities.

About 7000 students were enrolled, about 80 per cent of them men. Admission is by examination. Compulsory health examinations are given and excellent medical service provided free, even including visits. to the student's home. The university is located in a large city and provides no dormitories -which certainly affects library decisions. Fees are very low-less than $\$ 2$ - and many students from families with small income attend, often at considerable personal sacrifice. Many students depend upon the library for their textbooks. Although the study of English has become more popular, most of them know Castellana or Spanish best and, like U.S. students, definitely prefer books in their native language. Less than I per cent of the circulation of the main library is in foreign languages. Students generally are more mature though perhaps more emotional than those in the U.S. and evince far greater interest in national political matters. ${ }^{3}$

\section{The Libraries}

The library system of the university consists of a central library containing about 70,000 volumes and independent college or special libraries holding another 45,000. These various libraries were not coordinated at all, having no clear division of responsibilities, no unified budget, and no centralized purchasing, nor did they have the same classification system, if any, or a union catalog of holdings. The central library is a dependency of the rectorado or presidency, and the other libraries are subordinate to their own respective colleges.

The central library was crowded into several rooms, with almost no office space,

3 The Pan American Union series, Higher Education in Latin America, provides by far the best available information on South and Central American universities. Unfortunately, the volume. on Peru has not yet been published. 
and with seating for only about 60 students. The staff of 33 , including only one professionally trained person, were very seriously underpaid and their morale was low. The library was organized loosely into six departments without any very clear division of authority or responsibility. No associate or assistant director was provided, nor are such positions at all popular, partly because the libraries are not huge, partly as an administrative principle. A secretary really served as assistant director, but without the title or authority. The library had an author catalog of L.C. cards secured through Rockefeller Foundation aid and a rather crude list of general subjects in loose-leaf binders. Books were not classified by subject, but merely arranged on the shelves by accession number. Books were circulated overnight after 4:00 P.M., for the library collections were not adequate for both text and library purposes.

\section{International Problems}

No statement of library problems is complete without mentioning certain national and international aspects of library work that cannot be understood fully here in this country or that are not so important here. Peru is an importing nation, as is almost all of South America, and the librarian must secure from abroad all machines and equipment as well as most standard supplies. Now these imports must be paid for in U.S. dollars, the standard medium of exchange, but demand for dollars is always greater than the supply, and therefore the national government restricts purchases abroad. Since import permits are quite hard to get, especially for libraries, the result is that the librarian pays two or three times the normal price for his equipment, tries to get it made locally, or finally gives up and does without.

Another major problem is the lack of adequate trade or national bibliographies either for an individual country or for South America as a whole-no Publishers' Weekly, no Cumulative Book Index, no Publishers' Trade List Annual, no L.C. Catalog, no magazine indexes, and no general reviewing journals. The few national bibliographies issued annually are often one to three years late and not entirely practicable. ${ }^{4}$ Book selection and purchase therefore is a very difficult operation in Latin America, and further complicated by the fact that the great majority of publishing in Spanish is done in Argentina, Mexico and Spain, all of which demand payment in dollars. Finally, publications in other languages are not satisfactory for general use, yet translations of standard handbooks and texts cost two or three times the price of the original work.

A third problem arises from the recent origin of professional librarianship as such in South America. The first library school began only in 1925 and many of them are still irregular as to sessions, so that there is a lack both of sufficient trained personnel and of fundamental library tools. There is not available in Spanish for university libraries a satisfactory classification system, a good list of subject headings, a code of rules for cataloging, or satisfactory textbooks in book selection, cataloging, reference, or administration. ${ }^{5}$ North American tools have been and are used, but they should be adapted to Latin American needs, translated and printed for maximum effective usefulness. As to trained personnel, the nonprofessional period in U.S. libraries is long past and its implications more or less forgotten, but South America is still developing its professional attitudes and personnel, with all the accompanying difficulties

${ }^{4}$ Noteworthy is the quarterly Boletin Bibliografico Argentino.

${ }^{5}$ The best tools in Spanish probably are those issued by Espana Cuerpo Facultivo de Archiveros, Bibliotecarios y Archiveros. Some texts of varying quality for small public libraries have been published in Mexico, Cuba, Argentina and Brazil. 
and problems. Much progress is being made at present. ${ }^{6}$

\section{Reorganization}

In attempting to improve the libraries of the University of San Marcos, the work fell naturally into several broad categories: organization, personnel, techniques, library quarters and equipment, book collections and selection, coordination of university library resources, cooperative planning among the several national universities, and cooperation with other libraries on national problems. The main library was dealt with first, as it presented the most problems and was the key to the whole system.

Since the central library was not organized into well-defined functional divisions and since lines of authority were vague, the first step was to reorganize it into four main divisions, of public services, acquisitions, cataloging and classification, and reference. Reference was intended to be in public services but finally was created a separate division because of personnel problems. Each division was headed by a chief who had the title and definite powers and responsibilities assigned to him in writing. In order to carry the division of work still further and to help reduce personnel problems, each division was subdivided into logical sections with a chief for each section. In acquisitions, for example, there were sections for purchasing, gifts and exchanges, serials, and receiving. The receiving section also did the searching for items not handled by purchasing, and did immediate accessioning to reduce the possibility of theft. Binding was assigned to purchasing in order to consolidate expenditures and because most books came in paper covers and decisions regarding binding had to be made at once. The other di-

6 For good information on the state of library development in Latin America, see Assembly of Librarians of the Americas. Ist, Washington, D.C., 1947. Proceedings. Washington, Library of Congress, 1948 . visions were similarly subdivided. After the first two months, and when processes had become stabilized, each section began a staff manual of operations to standardize routines and for the training of new staff members. These were written by the supervisor himself in some cases.

\section{Personnel}

The success of the whole reorganization depended to a large extent upon how well problems of personnel could be overcome and the whole-hearted cooperation of the staff secured. Morale was very low, the fundamentals of library science were not well known, and additional people were needed. Contributing heavily to the problem of morale were salaries below the subsistence level and no salary schedule - almost the first official act had been to discharge three employees who had sold books from the library, been tried earlier by a faculty committee and proved guilty. Therefore, in conjunction with the reorganization plans and re-assignment of duties and titles, all salaries were raised by action of the University Council between 50 and 100 per cent. This quite naturally had a very beneficial effect. The assigning of definite titles, duties and privileges also helped, as did strict adherence to lines of authority, staff meetings, occasional staff parties, regular meetings of division chiefs, the beginning of instruction in library science, the purchase of much new equipment and supplies, and strong support from the rector and the University Council. Fifteen new persons were added, chiefly in technical processes where major effort was to be concentratedthe division of cataloging and classification grew from two to 15 persons. All new people were chosen carefully for ability, intelligence, and youthfulness, disregarding as far as possible the matter of political affiliation. It may be said that it is very difficult 
to eliminate politics completely under local control. It also should be said that the social customs and psychology of the people, as well as their principles and practices of administration, vary in some respects from the North American and that these differences must be understood and accounted for in successful personnel administration.

In order to overcome the lack of professional knowledge, training in fundamentals had to be secured. First efforts were to obtain personnel and training from the local library school of the National Library, a good school founded a few years earlier with the aid of U.S. teachers. However, it proved impossible to make any arrangements for training university staff members there, because political and personal differences existed between the administrations of the university and the National Library. Since training was fundamental to any degree of success, it was determined to offer four short courses of about one month each, in bibliography and book selection, circulation, cataloging and classification. The $\mathrm{Na}$ tional Library did loan some texts and one professor. Two professionally trained persons were secured to teach two of the courses, and the supervisor taught the others with aid from three staff members; the courses were very practical and filled the immediate need, but of course were no permanent substitute for regular library school work. Each course was available only to the staff of the department concerned, though some lectures, as on bibliography, were thrown open to others. A brief series of lectures on reference also was given, plus a final short course on the fundamentals of administration for the heads of divisions. At the request of the university administration, the supervisor also drew up plans and outlined courses for a regular library school. Subsequent political events may have eliminated the conflict with the National Library and rendered a second library school unnecessary.

\section{Technical Matters}

Following the internal reorganization and at least partial solution of problems of personnel, the next step was to investigate the routine operations and technical aspects of the library and then to bring them into line with commonly accepted practices when necessary. This proved to be one of the longest and most difficult tasks of the entire program, but since the processes that were adopted are commonly used in the U.S., only a brief review will be given. In cataloging and classification, for example, a card catalog of authors and subjects and titles (divided) was begun, a shelf-list and subject headings list started, the Library of Congress classification adapted to Peruvian needs and then adopted, and A.L.A. rules for cataloging used. The department also began classification of the entire collection, to be completed in three years, and carried out whatever recataloging was necessary at the same time. Mimeographing of catalog cards was begun, even though typing would have been slightly cheaper because of low labor costs, so that cards could be sent to or exchanged with the other national universities' libraries.

In acquisitions, a standard accession book was designed, order slips installed to pass on information to cataloging, a simple accounting system installed to provide up-todate information, arrangements made to secure discounts on purchases, official order forms developed and printed, and book plates prepared and bought. Procedures for handling gifts, exchanges, pamphlets, and serials were set up in considerable detail. In services, few changes were made other than to create a reference department, simplify the call slip, add another circulation window, and recommend the loan for one 
week of little-used books. The new reference division was placed in one end of the main reading room and provided with a collection, locked bookcases, and desks. Reference service was offered in three subject sections corresponding to the academic specialties of the staff.

\section{Library Quarters and Equipment}

Plans were afoot to move the entire university to a new campus, and the supervisor drew plans for a modern two story library building, but for the time being and for a few years to come the present quarters would have to serve. They consisted of seven rooms that were very poorly arranged, poorly lighted, and quite inadequate. In order to provide some additional space, a new reading room to seat 175 persons was built in an adjacent patio and another room added for cataloging and classification. The former reading room was turned over to acquisitions and space also was cleared for an office for the director of the library. The various patios were used some as study places, although library books could not be taken there; the only other reading space was the general assembly hall of the university adjacent to the library and seating about 250 people. These were all temporary expedients that were hardly satisfactory for library needs, but were the best that could be provided under the circumstances. Very satisfactory facilities will be provided on the new campus.

The university administration was generous in its financial support for these building changes and especially for new equipment. Only three desks, three old typewriters, no booktrucks, and other inadequate equipment were available. Added were a dozen desks, a dozen tables, eight typewriters, a mimeograph machine, visible files, filing cabinets, catalog cabinets, fluorescent lights, and other such items. Incidentally, the booktrucks were popular for riding until one culprit was caught. Supplies were bought in quantity rather than small lots. It should be mentioned that whenever possible all equipment and supplies were made locally according to detailed plans and specifications, and that generally they were quite satisfactory.

Perhaps library tools hardly are equipment, but they were even more essential and far harder to obtain. The very serious shortage of these had not been foreseen, but the Library of Congress came to the rescue very generously and supplied quickly on exchange account the necessary classification schemes, lists of subject headings, catalog rules, some bibliographical tools, and many basic texts in library science. These were in English, of course, but were the only satisfactory ones available anywhere quickly and certainly were most welcome. Attempts to secure import permits for the purchase of such essential tools were not successful, due to the dollar shortage, but the library did manage to secure examples of most Spanish tools or texts. Most of them were for small public libraries and not suitable for university library use.

\section{Book Collections and Book Selection}

The South American university librarian has far greater difficulty in book selection and acquisition than his North American contemporary, for he has no trade bibliographies, few or no national bibliographies, no general reviewing magazines, and he is severely handicapped by import and currency restrictions. $\mathrm{He}$ is generally opposed to the allocation of funds and extensive selection by faculty members, selection being a duty and right of the librarian, and he usually has a limited book and magazine budget anyway. Exchanges are looked upon as an important source of materials, far more so than in the U.S., probably in view of the 
universal currency and import restrictions. At San Marcos, the decision was made to allocate responsibilities for recommendations among the staff members according to their academic specializations, but this move was not popular within the library because any decentralization of authority was looked on with concern. Some policies that were adopted were to buy current material first until book funds were increased, to stop all buying in fields such as law and medicine having good separate collections already, to make tentative allocations of book funds to various academic subjects, to expand the subscription list, and to cease buying private collections. Although exchanges could be very valuable if they were organized properly, in actual practice they are not; a complete overhauling is needed if the system really is to work effectively. Exchanges would be one means of overcoming currency problems, but most of the difficulties of the present system could be overcome only through a successful international conference. As to the existing book collection, no attempt was made to evaluate it systematically because the task would have been quite difficult under the circumstances and because the administration was not particularly interested in this aspect of the work.

The whole problem of bibliography and book selection is a knotty one that cannot be solved by a nationalistic approach, but instead will require international cooperation for any satisfactory solution. This is a situation in which this country really could aid both libraries and scholars by providing some of the specialized techniques and some of the leadership that are necessary. Our own scholarship and libraries would benefit too. The annual Handbook of Latin American Studies helps but it only points the way.

\section{Coordination}

As was pointed out earlier, the university also maintained several college libraries totally independent of the main library, although closer cooperation would benefit everybody by eliminating duplication of effort, reducing costs of operation, and achieving a greater usefulness of the total library resources of the university. In order to explore some of these possibilities, the supervisor talked with the various librarians individually and then held a conference of all directors of libraries. They agreed unanimously to limit the departmental or college libraries to the college field and for the central library to stop buying books in law and medical fields and to transfer its useful holdings in these fields to the college libraries. All agreed to the beginning of a union catalog, to adopt the main library cataloging principles, and to delegate all cataloging and classification to the central library as soon as its own classification and recataloging job was finished. Upon the recommendation of the supervisor, the university administration decided to limit the size of college libraries on the new campus and to provide only working collections outside of the central library, as well as to establish a library council.

On a national level, a conference was held of directors of the national university libraries, and agreements were secured on an interlibrary loan code, exchanges of publications, establishment of a central author catalog at the University of San Marcos, exchange of cards, and other matters. However, some of the plans must await further developments, locally, for the other national university libraries had pressing internal problems of their own similar to those at San Marcos. Incidentally, it might be mentioned that the federal government forbade interlibrary loans out of the country, stating the uncertainties of postal service as the reason.

On the general professional level, it was recommended at the above conference that 
the National Library collect and publish statistics on libraries, that archival materials be collected systematically and cataloged, and that national subject bibliographies be made and published. Actually, much effective work remains to be done within individual libraries themselves before the broader problems can be attacked effectively, and other improvements require international rather than national action. The recent Assembly of Librarians of the Americas was a most auspicious step toward international cooperation.

\section{Conclusion}

Several broad conclusions regarding university libraries in South America may be drawn from this experience. In general, the libraries are just entering upon the stage of professional development and much progress is now being made with much more still to come. Many of their problems arise from this condition, but there are other and perhaps more serious difficulties that can be solved only by international cooperation in which U.S. librarians should take a part. All relations with these libraries must take into consideration their own special problems; it must not be assumed that they are exact counterparts of North American university libraries, and they never will be. Finally, the keystone to successful relations is sympathetic understanding - this is far more important than merely being able to speak their language - and can hardly be stressed sufficiently.

\section{Around the World with U. S. Libraries}

(Continued from page 325)

ment, as well as in the scientific and technological fields.

Schools and universities in some of the communist controlled countries avail themselves of the opportunity to obtain American books and magazines for the use of students and teachers. A collection of U.S. textbooks and readers recently made available to schools in one satellite country is reported to be serving dozens of classes in English language study. The themes of these carefully selected books are life in the U.S. and how democracy works. American librarians have been active in helping these overseas U.S. libraries to become the exciting places that they are-librarians from public libraries, special libraries, university libraries and the Library of Congress have all been in the field. Flora Belle Ludington, Wallace Van Jackson, Winifred Lindeman and many others have aided in the establishment of libraries which are worthy of praise. For openings in these libraries, the personality and professional re- quirements are high and the language qualifications stringent. The need is for men and women with professional training and broad experience, who have the ability to cut red tape and to operate efficiently with a skeleton staff of alien employees. The recruitment of such librarians is obviously difficult. To work as a part of a team, with the mission, with specialists in information, news, radio, and cultural activities; to know America thoroughly, but to be aware of the sensibilities of the people of the country in which one works; to know all levels of people; to have the ability to defend America through speeches and through quiet actions when occasion demands; to be never a passive citizen, but always actively to represent America-these responsibilities are not easy, in a strange land, with strange customs, with tools and equipment missing when most needed. But those librarians who have been with the U.S.I.E. program somehow believe in it and come back to work for it whether abroad or in the U.S. 